\title{
A Short Communication on Sequential and Structural Information's of Human Galanin Receptors using in Silico Methods
}

\author{
Gugan Kothandan ${ }^{\dagger}$
}

\begin{abstract}
Gal (1-3) receptors are members of GPCR superfamily with seven transmembrane helices. The neuropeptide galanin mediates its effects through the receptor subtypes Gal1, Gal2, and Gal3 and has been implicated in anxiety and depression related behaviors. Galanin receptors are considered to be important targets for the development of novel antidepressant drugs. Owing to the importance of these receptors, a short communication about the sequential and structural studies about the functional Galanin (1-3) receptors has been reported. Structural studies have been hampered due to the lack of Xray crystal structures. However with the availability of templates with close homologs comparative modeling could be encouraging. Sequence analysis was done for each receptors and homology modeling of each receptors were done with recently reported templates. Comparative analyses were done between these receptors to identify the relationships between them sequentially. Phylogram was generated between these receptors to identify the close homologue between this receptor and found that Gal2 and Gal3 receptors are closer. Our results could be useful for further structure based drug design targeting Gal1, Gal2 and Gal3 receptors.
\end{abstract}

Key words : Gal1, Gal2, Gal3, Galanin, Homology Modeling

\section{Introduction}

Galanin is a widely distributed peptide neurotransmitter that activates G-protein coupled receptors to regulate a range of physiological processes, including feeding, insulin release, lactation, spinal reflex, gut contractility, growth, learning, memory, and depression ${ }^{[1-4]}$. All 14 species homologs studied to date contain 29 amino acids and a carboxy-terminal amide, with the exception of human galanin which contains 30 residues (ending in Ser30) and a carboxyl free acid. All except tuna fish galanin ${ }^{[5]}$ share an absolutely conserved $\mathrm{NH}_{2}$-terminal region associated with biologic activity (residues 1-14) and a variant $\mathrm{COOH}$-terminal region ${ }^{[2,6]}$.In the rat, galanin has been shown to have physiological effects in feeding, insulin release, lactation, gut contractility, and growth and has effects on central functions such as spinal reflex, learning, and memory and in rodent models of depression. Three cloned galanin GPCRs have been

Department of Biohemistry, Centre for Bioinformatics, University of Madras, Guindy campus, Guindy, Chennai-600025, India

${ }^{\dagger}$ Corresponding author : guganmsc@gmail.com

(Received: August 12, 2012, Revised : September 20, 2012, Accepted : September 25, 2012) identified and are designated as Gal1, Gal2, and Gal $3^{[7,8]}$.

These Galanin receptors (1-3) are members of GPCR superfamily consist of seven transmembrane helices and they are among the preferred drug targets of the pharmaceutical industry. They have been implicated in anxiety and depression related behaviors and it has been mediated by the peptide termed as galanin neuropeptide. The pharmaceutical industry and academic researchers have been searching for non-peptide type galanin receptor ligands that would have better stability than galanin, the peptide that is metabolized within minutes in humans, and which would cross the blood-brain barrier to be able to act at the central galanin receptors.

In this short communication, Galanin receptors were selected for in silico studies. Till to date there is no Xray structural report on the family of these receptors. There was only one report on the modeling of N-terminal region of galanin and its interaction with galanin receptor ${ }^{[9]}$. However in that study the authors reported the interaction of N-gal with galanin subtype receptors. They obtained the Gal (1-3) receptors from ModBase database and analysis was done. With the availability of recently reported GPCR template structures, it could be interesting and useful to develop the homology models 
of Galanin receptors. This prompted us to initiate the analysis. This short study deals with the comparative modeling of Galanin receptors using recently reported template structures. Comparative analyses were done between these receptors to identify the relationships between them. We hope that our results could be helpful for future prospects.

\section{Experimental Section}

All molecular modeling calculations were performed using molecular modeling programs, Sybyl 8.1 and Modeller installed on a Linux environment.

\subsection{Sequence Analysis of Galanin Receptors}

The amino acid sequences of human Galanin receptors were retrieved from the Uniprot KB/TrEMBL database. The sequences of galanin receptors were further used for template identification using the basic local alignment search tool for protein (BLAST) algorithm $^{[10,11]}$ against the protein data bank ${ }^{[12]}$. After the search, the alignment between the template and the target sequences was performed using ClustalW 2.0 $0^{[13]}$.

\subsection{Homology Modeling of Galanin Receptors}

Homology modeling of each galanin receptor was performed using the Modeller9v4 program ${ }^{[14-16]}$. Ten such 3D models were generated for these Galanin receptors with the alignment obtained using number of homologous template structures from the PDB for further computational study. Finally a model with the lower Molpdf (molecular probability density function) score and no significant main chain root mean square (RMS) deviation was selected. The selected models of Galanin receptors were refined by simple energy minimization and were further validated using PROCHECK ${ }^{[17]}$.

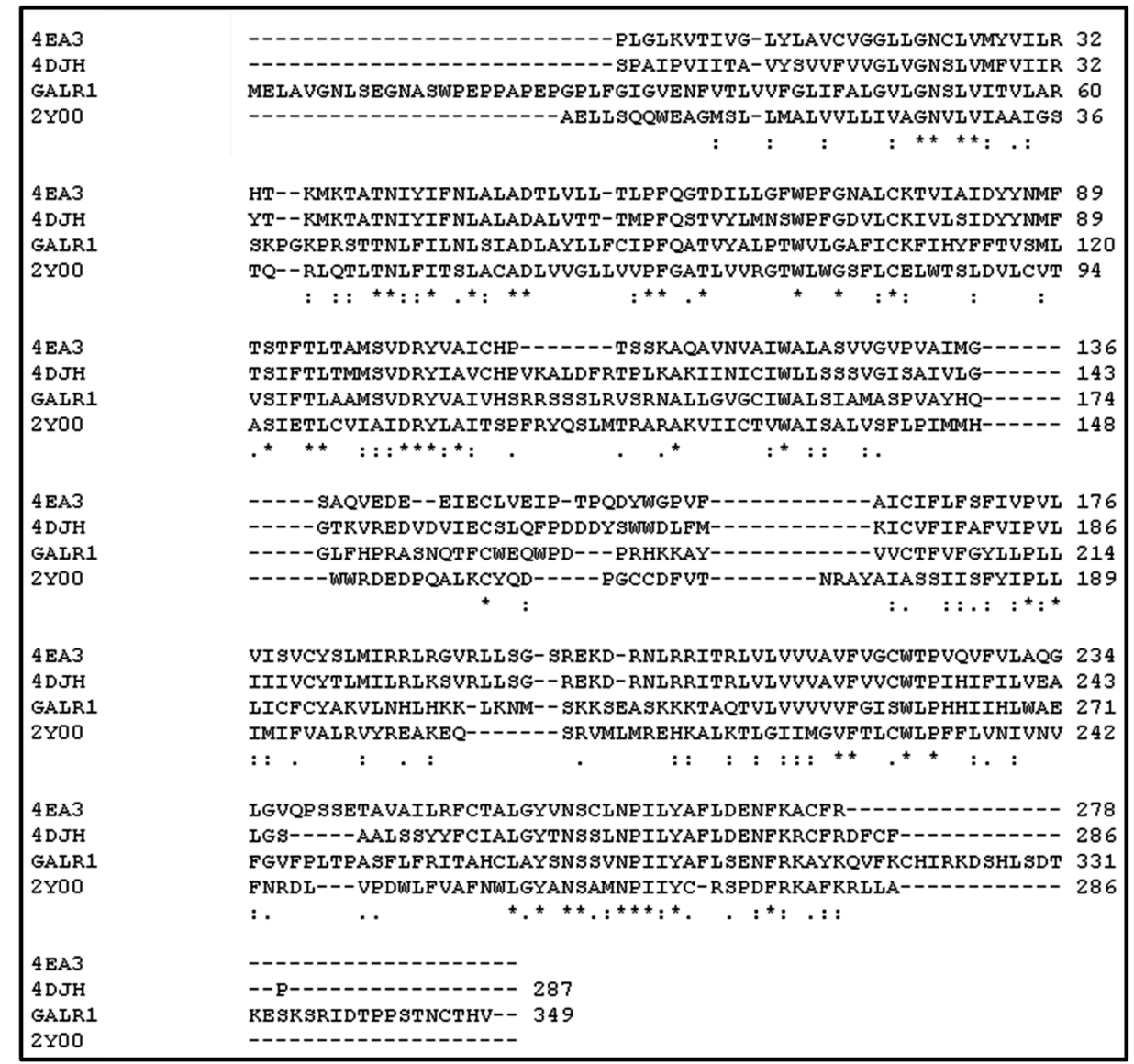

Fig. 1. Sequence alignment between GAL1 and A chain of the top template structure hits. 


\section{Results and Discussion}

\subsection{Sequence Analysis of Galanin Receptors}

In order to identify adequate template structures for each Galanin receptor modeling, Blast search was done. The search using Blast algorithm against the PDB revealed numerous potential templates for modeling. The Uniprot sequence of Gall (P47211) was retrieved from Uniprot database. Among the template hits, three top structures were selected as template hits. Top templates used for modeling was N/OFQ Opioid Receptor (PDB code: 4EA3) ${ }^{[18]}$, Beta1 Adrenergic Receptor (PDB code: $2 \mathrm{Y} 00)^{[19]}$ and human kappa opioid receptor (PDB code: $4 \mathrm{DJH})^{[20]}$. The sequence identity between Galanin1 N/OFQ Opioid Receptor was found to be $34 \%$ with query coverage of $80 \%$. Similarly, the identity between Gall and Betal Adrenergic Receptor was found to be $29 \%$ with query coverage of $83 \%$. The final template human kappa opioid receptor shared an identity of $39 \%$ and the query coverage was found to be $70 \%$. The sequence conservation and the alignment were obtained using ClustalW and are shown in Fig. 1.

Similarly, the Uniprot sequence of Gal2 (O43603) was retrieved from Uniprot database. Top templates used for modeling was N/OFQ Opioid Receptor (PDB code: 4EA3) ${ }^{[18]}$, mu-opioid receptor (PDB code: $4 \mathrm{DKL})^{[21]}$ and human kappa opioid receptor (PDB code: $4 \mathrm{DJH})^{[20]}$. The sequence identity between Gal2 and N/OFQ Opioid Receptor was found to be 35\% with query coverage of $71 \%$. Similarly, the identity between Gal2 and mu-opioid receptor was found to be $34 \%$ with query coverage of $73 \%$. The final template human kappa opioid receptor shared an identity of $33 \%$ and the query coverage was found to be $71 \%$. The sequence

\begin{tabular}{|c|c|}
\hline $4 \mathrm{DKL}$ & - \\
\hline $4 \mathrm{DJH}$ & 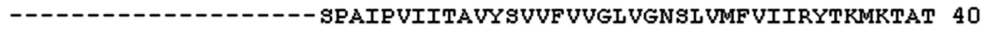 \\
\hline 4EA3 & 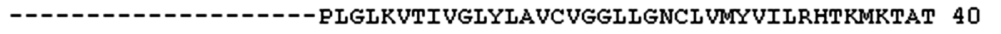 \\
\hline \multirow[t]{2}{*}{ GALR2 } & MNVSGCPGAGNASQAGGGGGWHPEAVIVPLLFALIFLVGTVGNTLVLAVLLRGGOAVSTT 60 \\
\hline & $:::::::^{*} .^{* *} *^{*}:{ }^{*}::^{*}:::^{*}$ \\
\hline $4 \mathrm{DKL}$ & NIYIFNLALADA-LATSTLPFQSVNYLMGTWPFGNILCKIVISIDYYNMFTSIFTLCTMS 98 \\
\hline $4 \mathrm{DJH}$ & NIYIFNLALADA-LVTTTMPFQSTVYLMNSWPFGDVLCKIVLSIDYYNMFTSIFTLTMMS 99 \\
\hline 4 EA3 & NIYIFNLALADT-LVLLTLPFOGTDILLGFWPFGNALCKTVIAIDYYMMFTSTFTLTAMS 99 \\
\hline \multirow[t]{2}{*}{ GALR2 } & NLFILNLGVADLCFILCCVPFOATIYTLDGWVFGSLLCKAVHFLIFLTMHASSFTLAAVS 120 \\
\hline & 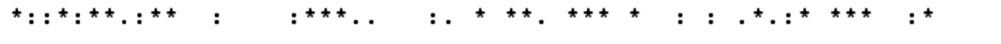 \\
\hline $4 \mathrm{DKL}$ & VDRYIAVCHPVKALDFRTPRNAKIVNVCNWILSSAIGLPVMFMATTKYRQ--GSIDCTLT 156 \\
\hline $4 \mathrm{DJH}$ & VDRYIAVCHPVKALDFRTPLKAKIINICIWLLSSSVGISAIVLGGTKVREDVDVIECSLQ 159 \\
\hline 4EA3 & VDRYVAICHP-------TSSKAQAVNVAIWALASVVGVPVAIMGSAQVED--EEIECLVE 150 \\
\hline \multirow[t]{2}{*}{ GALR2 } & LDRYLAIRYPLHSRELRTPRNALAAIGLIWGLSLLFSGPYLSYYRQSQLA--NLTVCHPA 178 \\
\hline & 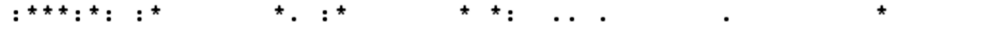 \\
\hline $4 \mathrm{DKL}$ & FS-HPTWIWENLLKICVFIFAFIMPVLIITVCYGLMILRL-KSVRE--------KDRNLR 206 \\
\hline $4 \mathrm{DJH}$ & FPDDDYSWWDLFMKICVFIFAFVIPVLIIIVCYTLMILRL-KSVR-LLSG-RE-KDRNLR 215 \\
\hline 4 EA3 & IP-TPQDYWGPVFAICIFLFSFIVPVLVISVCYSLMIRRL-RGVR-LLSG-SREKDRNLR 206 \\
\hline \multirow{2}{*}{ GALR2 } & WS----APRRRAMDICTFVF SYLLPVLVLGLTYARTLRYLWRAVD-PVAA-GSGARRAKR 232 \\
\hline & 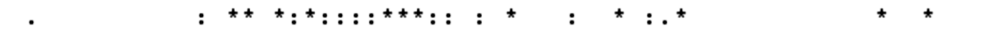 \\
\hline $4 \mathrm{DKL}$ & RITRMVLVVVAVFIVCWTPIHIYVIIKAIITIPETTFQTVSWHFCIALGYTNSCLNPVLY 266 \\
\hline $4 \mathrm{DJH}$ & RITRLVLVVVAVFVVCWTPIHIFILVEALGS-----AALSSYYFCIALGYTNSSLNPILY 270 \\
\hline 4 EA3 & RITRLVLVVVAVFVGCWTPVQVFVLAQGLGVQRSSETAVAILRFCTALGYVNSCLNPILY 266 \\
\hline \multirow[t]{2}{*}{ GALR2 } & KVTRMILIVAALFCLCWMPHHALILCVWFGOFPLTRATYALRILSHLVSYANSCVNPIVY 292 \\
\hline & 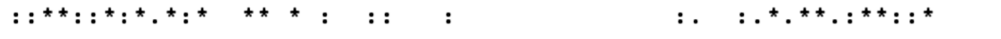 \\
\hline $4 \mathrm{DKL}$ & AFLDENFKRCF-- \\
\hline $4 \mathrm{DJH}$ & AFLDENFKRCF-- \\
\hline 4 EA3 & AFLDENFKACF-- \\
\hline \multirow[t]{2}{*}{ GALR2 } & ALVSKHFRKGFRTICAGLLGRAPGRASGRVCAAARGTHSGSVLERESSDLLHMSEAAGAL 352 \\
\hline & ${ }^{*}:::::^{*}: \quad * \quad *$ \\
\hline $4 \mathrm{DKL}$ & 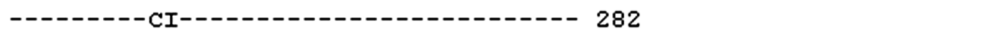 \\
\hline $4 \mathrm{DJH}$ & 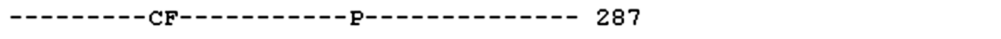 \\
\hline 4EA3 & 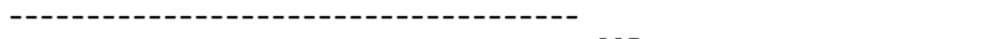 \\
\hline GALR2 & RPCPGASQPCILEPCPGP SWQGPKAGDSILTVDVA-- 387 \\
\hline
\end{tabular}

Fig. 2. Sequence alignment between GAL2 and A chain of the top template structure hits. 


\begin{tabular}{|c|c|c|}
\hline $4 \mathrm{DKL}$ & $-----------M V T A I T I M A L Y S I V C V V G L F G N F L V M Y V I V R-----Y T K M K T A T N I Y$ & 42 \\
\hline $4 \mathrm{DJH}$ & ---------- SEAIPVIITAVYSVVFVVGLVGNSLVMFVIIR-----YTKMKTATNIY & 43 \\
\hline 4 EA3 & ----------PLGLKVTIVGLYLAVCVGGLLGNCLVMYVILR-----HTKMKTATNIY & 43 \\
\hline \multirow[t]{2}{*}{ GALR3 } & MADAQNISLDSPGSVGAVAVPVVFALIFLLGTVGNGLVLAVLLQPGP SAWQEPGSTTDLF & 60 \\
\hline & $: \quad: \quad:: \quad: \quad: *{ }^{* *} * *: *:::$ & \\
\hline $4 \mathrm{DKL}$ & IFNLALADA-LAT STLPFQSVNYLMGTWPFGNILCKIVISIDYYNMFT SIFTLCTMSVDR & 101 \\
\hline 4DJH & IFNLALADA-LVTTTMPFQSTVYLMNSWPF GDVLCKIVLSIDYYNMFT SIFTLTMMSVDR & 102 \\
\hline $4 \mathrm{EA} 3$ & IFNLALADT-LVLLTLPFQGTDILLGFWPFGNALCKTVIAIDYYMMFT STFTLTAMSVDR & 102 \\
\hline \multirow[t]{2}{*}{ GALR3 } & ILNLAVADLCFILCCVPFOATIYTLDAWLFGALVCKAVHLLIYLTMYASSFTLAAVSVDR & 120 \\
\hline & 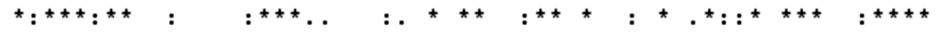 & \\
\hline $4 \mathrm{DKL}$ & YIAVCHPVKALDFRTRRNAKIVNVCNWILSSAIGLPUMFMATTKYRQ--GSIDCTLTFS- & 158 \\
\hline $4 \mathrm{DJH}$ & YIAVCHPVKALDFRTPLKAKIINICIWLLSSSVGISAIVLGGTKVREDVDVIECSLOFPD & 162 \\
\hline $4 \mathrm{EA} 3$ & YVAICHP-------TSSKAQAVNVAIWALASVVGVPVAIMGSAQVED--EEIECLVEIP- & 152 \\
\hline \multirow[t]{2}{*}{ GALR3 } & YLAVRHPLRSRALRTPRNARAAVGLVWLLAALF SAPYLSYYGTVRYG- - ALELCVPAW-- & 176 \\
\hline & 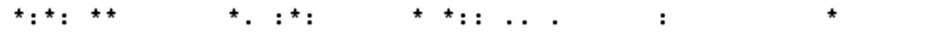 & \\
\hline $4 \mathrm{DKL}$ & HPTWYWENLLKICVFIFAFIMPVLIITVCYGLMILRLKSVRE---------KDRNLRR & 207 \\
\hline $4 \mathrm{DJH}$ & DDYSWWDLFMKICVFIFAFVIPVLIIIVCYTLMILRLKSVR-ILSGR----E-KDRNLRR & 216 \\
\hline $4 \mathrm{EA} 3$ & TPQDYWGPVFAICIFLF SFIVPVLVISVCYSLMIRRLRGVR-ILSG-S---REKDRNLRR & 207 \\
\hline \multirow[t]{2}{*}{ GALR3 } & --EDARRRALDVATFAAGYLIPVAVVSLAYGRTLRFLWAAV-GRAG-AAAAEARRRATGR & 232 \\
\hline & $:::^{*} \quad .:::^{*}::::^{*}:{ }^{*} \ldots \quad:{ }^{*}$ * & \\
\hline $4 \mathrm{DKL}$ & ITRMVLVVVAVFIVCWTPIHIYVIIKALITIPETTFQTVSWHFCIALGYTNSCLNPVLYA & 267 \\
\hline $4 \mathrm{DJH}$ & ITRLVLVVVAVFVVCWTPIHIFILVEALGS-----AALSSYYFCIALGYTNSSLNPILYA & 271 \\
\hline $4 \mathrm{EA} 3$ & ITRLVLVVVAVFVGCWTPVQVFVLAQGLGVQPSSETAVAILRFCTALGYVNSCLNPILYA & 267 \\
\hline \multirow[t]{2}{*}{ GALR3 } & AGRAMLAVAALYALCWGPHHAIILCFWYGRFAF SPATYACRLASHCLAYANSCLNPLVYA & 292 \\
\hline & * : * *.*: : ***: : : : & \\
\hline $4 \mathrm{DKL}$ & FLDENFKRCFR-- & 282 \\
\hline $4 \mathrm{DJH}$ & 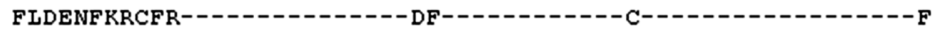 & 286 \\
\hline $4 \mathrm{EA} 3$ & FLDENFKACFR- - & 278 \\
\hline \multirow[t]{2}{*}{ GALR3 } & LASRHFRARFRRLWPCGRRRRHRARRALRRVRPASSGPPGCPGDARP SGRLLAGGGQGPE & 352 \\
\hline & $: \ldots:^{*}:{ }^{*}$ & \\
\hline $4 \mathrm{DKL}$ & ----------- & \\
\hline $4 \mathrm{DJH}$ & 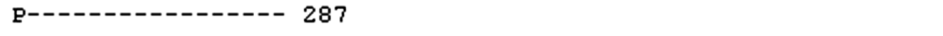 & \\
\hline 4EA3 & 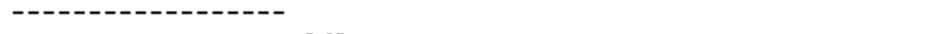 & \\
\hline GALR3 & PREGPVHGGEAARGPE-- 368 & \\
\hline
\end{tabular}

Fig. 3. Sequence alignment between GAL3 and A chain of the top template structure hits.

conservation and the alignment were obtained using ClustalW and are shown in Fig. 2.

Likewise, the Uniprot sequence of Gal3 (O60755) was retrieved from Uniprot database. Top templates used for modeling was N/OFQ Opioid Receptor (PDB code: 4EA3 $)^{[18]}$, mu-opioid receptor $(\mathrm{PDB} \text { code: } 4 \mathrm{DKL})^{[21]}$ and kappa opioid receptor (PDB code: $4 \mathrm{DJH})^{[20]}$. The sequence identity between Gal3 and N/OFQ Opioid Receptor was found to be $33 \%$ with query coverage of $74 \%$. Similarly, the identity between Gal3 and mu-opioid receptor was found to be $31 \%$ with query coverage of $76 \%$. The final template human kappa opioid receptor shared an identity of $31 \%$ and the query coverage was found to be $76 \%$. The sequence conservation and the alignment were obtained using ClustalW and are shown in Fig. 3.

\subsection{Homology Modeling of Galanin Receptors}

The coordinates of the crystal structures of respective template hits were used to build the homology model of Galanin receptors (Gal 1-3). In these models, the seven transmembrane (TM) helixes were properly transformed according to that of the template structures. The three dimensional homology models of Galanin receptors were generated using Modeller9v4 program. Ten models were developed for each receptor and finally the model with the lowest MolPdf as well as with the lowest RMSD was selected and it is shown in Fig. 4. The selected models were further validated stereochemically using additional parameters such as the PROCHECK plots. The statistical parameters obtained for the Galanin models are summarized in Table 1. 


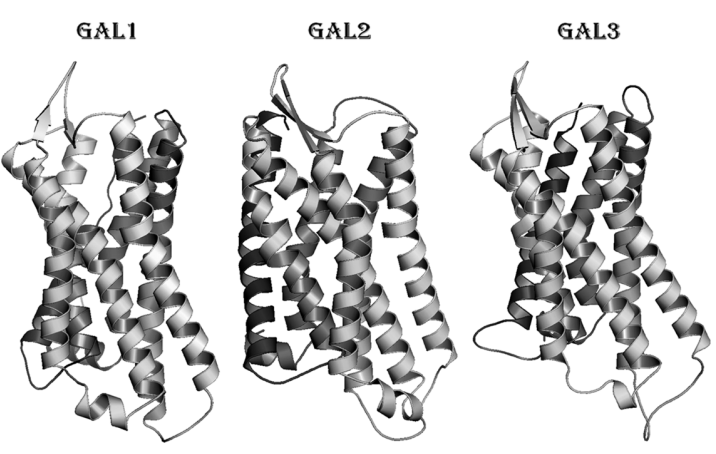

Fig. 4. Homology models of Galanin receptor structures Seven transmembrane helices are colored in different color codings. N-Terminal and C-Terminal loop regions are deleted for clarity

\subsection{Sequence Analysis of Human Functional Galanin Receptors}

Sequence analysis between these Galanin receptors was done using ClustalW and the relationship between these receptors was analyzed sequentially. Phylogram
Table 1. Validation results of Galanin receptor homology models

\begin{tabular}{ccccc}
\hline \multirow{4}{*}{ Model } & \multicolumn{4}{c}{ Procheck } \\
\cline { 2 - 5 } & $\begin{array}{c}\text { Core } \\
\%\end{array}$ & $\begin{array}{c}\text { Generously } \\
\text { allowed \% }\end{array}$ & $\begin{array}{c}\text { Additionally } \\
\text { allowed \% }\end{array}$ & $\begin{array}{c}\text { Disallowed } \\
\%\end{array}$ \\
\hline Gal1 & 93.5 & 5.2 & 0.3 & 1.0 \\
Gal2 & 92.4 & 4.6 & 2.1 & 0.9 \\
Gal3 & 90.9 & 5.5 & 1.9 & 1.6 \\
\hline
\end{tabular}

was generated to analyze the phylogenetic relationship between these receptors. Our results found that Gal2 and Gal3 receptors shared more identity than others. It was identified that Gall and Gal2 shared an identity of $36 \%$, whereas Gall and Gal3 shared the sequence identity of $33 \%$. It was found that Gal2 and Gal3 shared an identity of $53 \%$. Overall, our sequence analysis found that Gal2 and Gal3 receptor are found to be close. Phylogram results confirmed that both Gal2 and Gal3 are closer than Gall. The alignment obtained between these

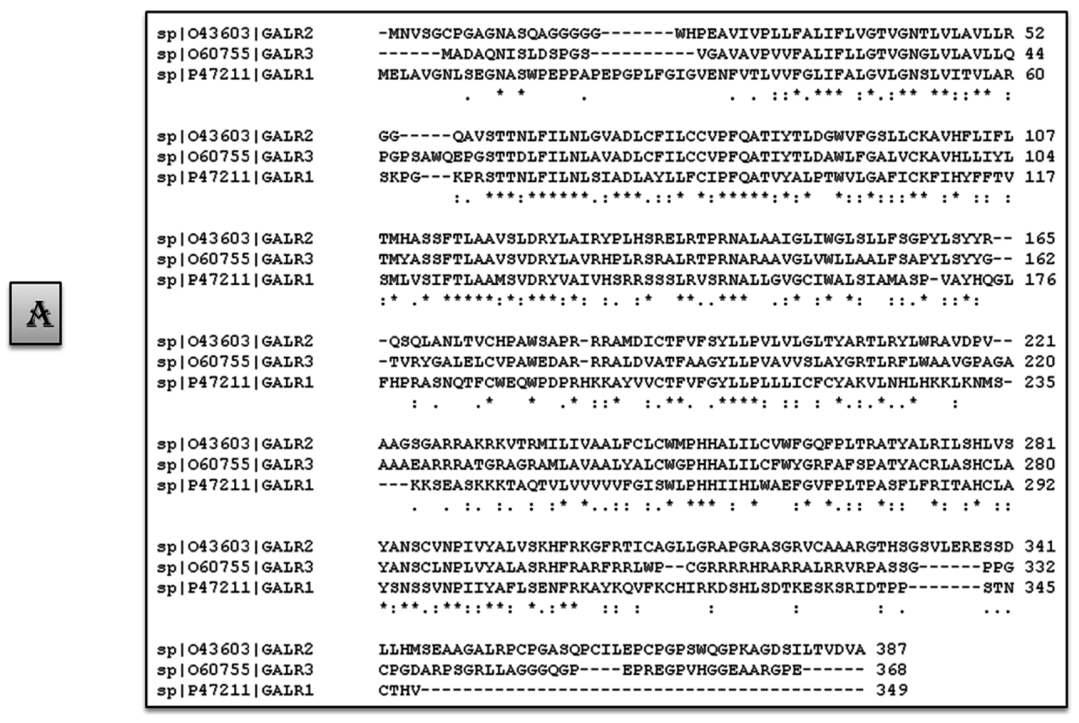

B

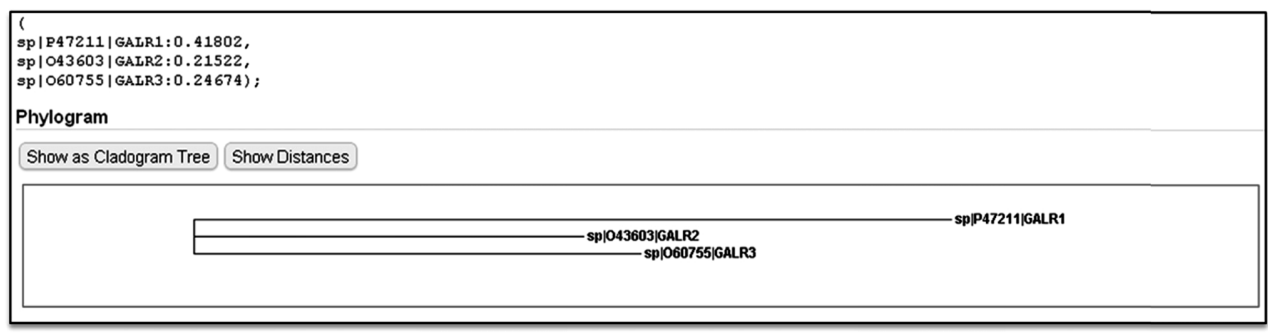

Fig. 5. Sequence alignment between Galanin receptors and the phylogenetic evolution between these receptors. 
receptors and the phylogram developed between these receptors with their distances is shown in Fig. 5.

\section{Conclusion}

In this short communication, sequence analysis was done for each galanin receptor to identify the template structures for modeling. Homology modeling was then performed to develop the homology models of Galanin receptors using the more recently reported template structures. Comparative analyses were done between these receptors to identify the relationships between them. We hope that our results could be useful for further structure based drug design targeting Gal1, Gal2, and Gal3 receptors.

\section{References}

[1] T. Bartfai, T. Hokfelt, and U. Langel, "Galanin: A neuroendocrine peptide", Crit. Rev. Neurobiol., Vol. 7, pp. 229-274, 1993.

[2] K. Bedecs, M. Berthold, and T. Bartfai, "Galanin: 10 years with a neuroendocrine peptide", Int. J. Biochem. Bell. Biol., Vol. 27 pp. 337-349, 1995.

[3] K. Kask, M. Berthold, and T. Bartfai, "Galanin receptors: Involvement in feeding, pain, depression and Alzheimer's disease", Life Sci., Vol. 60, pp. 1523-1533, 1997.

[4] K. Kask, U. Langel, and T. Bartfai, "Galanin: A neuropeptide with inhibitory actions", Cell. Mol. Neurobiol., Vol. 15, pp. 653-673, 1995.

[5] H. Kakuyama, A. Kuwahara, T. Mochizuki, M. Hoshino, and N. Yanaihara, "Role of N-terminal active sites of galanin in neurally evoked circular muscle contractions in the guinea-pig ileum", Eur. J. Pharmacol., Vol. 329, pp. 85-91, 1997.

[6] J. Lundkvist, T. Land, U. Kahil, K. Bedeces, and T. Bartfai, "cDNA sequence, ligand binding, and regulation of galanin/GMAP in mouse brain", Neurosci. Lett., Vol. 200, pp. 121-124, 1995.

[7] T. A. Branchek, K. E. Smith, C. Gerald, and M. W. Walker, "Galanin Receptor Subtype", Trends Pharmacol. Sci., Vol. 21, pp. 109-116, 2000.

[8] S. M. Foord, T. I. Bonner, R. R. Neubig, E. M. Rosser, J. P. Pin, A. P. Davenport, M. Spedding, and A. J. Harmar, "International Union of Pharmacology. XLVI. G Protein-Coupled Receptor List”, Pharmacol. Rev., Vol. 57, pp. 279-288, 2005.

[9] M. Parthiban and P. Shanmughavel, "Three dimen- sional modeling of $\mathrm{N}$-terminal region of galanin and its interaction with the galanin receptor", Bioinformation., Vol. 2, No. 3, pp. 119-125, 2007.

[10] S. F. Altschul, W. Gish, W. Miller, E. W. Myers, and D. J. Lipman, "Basic local alignment search tool", J. Mol. Biol., Vol. 215, pp 403-410, 1990.

[11] S. F. Altschul, T. L. Madden, A. A. Schaffer, J. Zhang, Z. Zhang, W. Miller, and D. J. Lipman, "Gapped BLAST and PSI-BLAST: a new generation of protein database search programs", Nucleic. Acids. Res., Vol. 50, pp. 3389-3402, 1997.

[12] H. M. Berman, J. Westbrook, Z. Feng, G. Gilliland, T. N. Bhat, H. Weissig, I. N. Shindyalov, and P. E. Bourne, "The protein data bank", Nucleic. Acids. Res., Vol. 28, pp. 235-242, 2000.

[13] J. D. Thompson, D. G. Higgins, and T. J. Gibson, "CLUSTAL W: improving the sensitivity of progressive multiple sequence alignment through sequence weighting, position-specific gap penalties and weight matrix choice", Nucleic. Acids. Res., Vol. 22, pp. 4673-4680, 1994.

[14] N. Eswar, B. John, N. Mirkovic, A. Fiser, V. A. Ilyin, U. Pieper, A. C. Stuart, M. A. Marti-Renom, M. S. Madhusudhan, B. Yerkovich, and A. Sali, "Tools for comparative protein structure modeling and analysis", Nucleic. Acids. Res., Vol. 31, pp. 3375-3380, 2003.

[15] A. Sali and T. L. Blundell, "Comparative protein modeling by satisfaction of spatial restraints", J. Mol. Biol., Vol. 234, pp. 779-815, 1993.

[16] A. Fiser, R. K. Do, and A. Sali, "Modeling of loops in protein structures", Protein Sci., Vol. 9, pp. 17531773, 2002.

[17] R. A. Laskowski, M. W. MacArthur, D. S. Moss, and J. M. Thornton, "Procheck-a program to check the stereochemical quality of protein structures", J. Appl. Cryst., Vol. 26, pp. 283-291, 1993.

[18] A. A. Thompson, W. Liu, E. Chun, V. Katritch, H. Wu, E. Vardy, X. P. Huang, C. Trapella, R. Guerrini, G. Clo, B. L. Roth, V. Cherezov, and R. C. Stevens, "Structure of the nociceptin/orphanin FQ receptor in complex with a peptide mimetic", Nature, Vol. 485 , pp. 395-399, 2012.

[19] T. Warne, R. Moukhametzianov, J. G. Baker, R. Nehme, P. C. Edwards, A. G. Leslie, G. F. Schertler, and C. G. Tate, "The structural basis for agonist and partial agonist action on a $\beta(1)$-adrenergic receptor", Nature, Vol. 469, pp 241-244, 2011.

[20] H. Wu, D. Wacker, M. Mileni, V. Katritch, G. W. Han, E. Vardy, W. Liu, A. A. Thompson, X. P. Huang, F. I. Carroll, S. W. Mascarella, R. B. West- 
kaemper, P. D. Mosier, B. L. Roth, V. Cherezov, and R. C. Stevens, "Structure of the human $\kappa$-opioid receptor in complex with JDTic", Nature, Vol. 485, pp. 327-332, 2012.

[21] A. Manglik, A. C. Kruse, T. S. Kobilka, F. S. Thian,
J. M. Mathiesen, R. K. Sunahara, L. Pardo, W. I. Weis, B. K. Kobilka, and Sébastien Granier, "Crystal structure of the $\mu$-opioid receptor bound to a morphinan antagonist", Vol. 485, pp. 321-326, 2012. 